\title{
“Online CPD courses: Do they enhance student knowledge?"
}

\author{
Scott Malcolm Goudie \\ University of Greenwich
}

Most professional bodies require registrants to demonstrate a commitment to continuing professional development (CPD). During the re-registration process, the registrant's CPD folder may be audited by her/his registering body to check that the registrant has evidenced the knowledge, skills and experience gained throughout that period of professional practice.

Anticipation of a CPD audit leads many professionals to search for quick, easy and often free CPD courses that can be evidenced in their portfolio. The internet has become saturated with free courses relating to all disciplines of CPD for professional practice. Many employers also use an online course method to ensure that employees meet statutory and mandatory training needs for each year.

In recent years, online CPD courses have become far more commonplace. It is easy to see why: materials are widely accessible to all and may be enhanced with seemingly endless technological possibilities - audio, visual, animation, conferencing, discussion forums, social networking - all of which help to give the student a richer learning experience (Harish, 2013). Strong consideration is given to financial cost. Once course materials have been developed, little remains to enable that course to run effectively. Administration, consumables, wages and expenses are just some of the costs reduced by transferring materials online (Herman and Banister, 2007).

Moving to online courses seems logical, given the time and monetary constraints placed on modern businesses. The ability to 'tick the box', as confirmation that employees have complied with yearly requirements, is a necessity and employees want quick courses that provide them with evidential CPD certificates. But are these online courses fit for purpose? What pedagogy is used to facilitate learning?

Recent personal experience would suggest that the raison d'être of some courses is merely to 'tick the box' rather than to educate students meaningfully. Having undertaken several online courses billed as 'essential' training, I was able to complete them without having to open any online learning materials - I was able to skip straight to the course assessment and take them immediately. The answers to most multi-choice questions were guessable and I could address the more difficult questions by a logical process of elimination. At no point was reference to learning material required in order to answer a question. Furthermore, if I failed any CPD test, the consequent provision of correct answers enabled me immediately to repeat them and attain perfect scores - in subjects I profess not to know much about!

I have complied with mandatory training and can evidence my CPD - but have I learnt anything? Superficially, this may seem a win/win situation. I have certificates and have met statutory requirements. What does this mean for the competence of individuals and whole professions? If unchecked, this type of emergent CPD runs the risk of misrepresenting the competence and thus undermining the credibility of the professions involved. 
Zimmerman (2012) states that "learner-content interaction is an essential element of the learning process" and satisfaction should be derived from the fact that subject knowledge has increased. However, the design process of these CPD courses is lacking in this regard. Akyol and Garrison (2011) recommend that focus be placed on linking cognitive learning processes to the learning outcomes of materials, so as to gauge whether learning has occurred. This cannot occur in assessment in which answers can be guessed or logically deduced.

An important factor in the learning process is learner compliance. It is often difficult for a student to engage with mandatory training, as the subject matter is rarely of interest. If a student is to approach and engage with learning in a deep, meaningful manner, the material framework needs to promote inquiry, whereby the student will develop and enhance their knowledge by constructing their own personal learning experience, developing existing knowledge and obtaining new information (Akyol and Garrison, 2011). This approach must excite the student and maintain engagement throughout in order to work.

To encourage students to read subject material, it may be worth including a productive failure assessment prior to release of the course material. This involves the students answering questions which s/he may fail, highlighting specific knowledge gaps in areas that require exploration in greater depth and detail (Sharples et al., 2016). This form of enquirybased learning requires - and therefore encourages - students to delve into areas where their knowledge/understanding is weak before they can successfully undertake final assessment. Only once students have undertaken this should they be able to access the certificate. Failure in one particular area should require the student to revisit it in order to understand why s/he answered incorrectly: real learning is achieved not by the giving of the answer, but rather by the provision of a problem-based learning situation that will lead to discovery of the answer through engagement with the material.

In the quest to ensure that professionals are keeping up to date, paper certificates have replaced the genuine requirement for sound and meaningful acquisition of knowledge. Online CPD courses should be scrutinised for design and relevant pedagogical merits. It is time for professional bodies to look at what effect this could have on their registrants and devise methods of accrediting individual CPD courses according to the positive impact they can have on professional development.

For convenience, many time-constrained professionals seek sanctuary in online teaching materials, which by their very nature, are asynchronous. Both Pelz (2004) and Sharples (2016) recommend the use of online materials, as students are in their own environment and engage with the materials when they feel comfortable and ready. This allows them to analyse and digest the information and then undertake assessment when ready to do so; this engages everyone and removes the immediacy of traditional classroom teaching. Massive open online courses (MOOCs) could be used to facilitate real-time group CPD sessions, allowing professionals with united interests to collaborate and disseminate knowledge and research through discussion. Sharples (2016) recommends that webdesigners, academics and educational technologists should collaborate to improve technological pedagogy.

Professionals should be encouraged to participate in meaningful CPD, in order to demonstrate a positive approach to reflective learning and so contribute to the development 
of their profession. Newer emergent technologies will hopefully bring about change in attitudes and behaviours relating to course design and encourage a positive pedagogy. In a world where time and money are considered crucial elements of course design, it can only be hoped that behaviours dictated exclusively by time and money do not become pandemic and hinder the development of the very professions they inhabit and profess to enhance.

\section{Reference list}

Akyol, Z. and Garrison, R. (2011) 'Understanding Cognitive Presence in an Online and Blended Community of Inquiry: Assessing Outcomes and Processes for Deep Approaches to Learning.' British Journal of Educational Technology, 42, 233-250.

Harish, J. (2013) 'Online Education: A Revolution in the Making.' Cadmus: Promoting Leadership in Thought that Leads to Action, 2(1), October. Available at: http://cadmusjournal.org/files/pdfreprints/vol2issue1/reprint-cj-v2-i1-online-educationiharish.pdf (Accessed: 7 August 2017).

Herman, T. and Banister, S. (2007) 'Face-To-Face Versus Online Coursework: A Comparison of Costs and Learning Outcomes.' Contemporary Issues in Technology and Teacher Education, 7(4), 318-326.

Pelz, B. (2004) '(My) Three Principles of Effective Online Pedagogy.' Journal of Asynchronous Learning Networks, 8(3), 33-46.

Sharples, M. (2016) 'Digital Education: Pedagogy Online.' Nature: International Journal of Science, 540, 340.

Sharples, M., de Roock, R., Ferguson, R., Gaved, M., Herodotou, C., Koh, E., KukulskaHulme, A., Looi, C-K., McAndrew, P., Rienties, B., Weller, M. and Wong, L. (2016) Innovating Pedagogy 2016. Open University Innovation Report 5. Milton Keynes: The Open University.

Zimmerman, T. (2012) 'Exploring Learner to Content Interaction as a Success Factor in Online Courses.' The International Review of Research In Open and Distributed Learning, 13(4). Available at: http://www.irrodl.org/index.php/irrodl/article/view/1302/2294 (Accessed: 7 August 2017). 